Jurnal Literasi Perpustakaan dan Informasi UHO, Volume 1, No. 1, Februari 2021, hlm X ISSN XXXX-XXXX (Print) ISSN XXXX-XXXX (Online)

\title{
ETIKA PROFESI PUSTAKAWAN DALAM PRAKTIK PELAYANAN DI PERPUSTAKAAN DAERAH KOLAKA UTARA
}

\author{
Muflii $^{1}$, Asrul Jaya ${ }^{2}$, Joko $^{3}$ \\ 123 Prodi Perpustakaan dan Ilmu Informasi Universitas Halu Oleo, Jl. H.E.A. Mokodompit No.1, Kota \\ Kendari, Indonesia \\ Email: tangsihmufli@gmail.com
}

\begin{abstract}
ABSTRAK
Tujuan penelitian ini adalah untuk mengetahui Etika Profesi Pustakawan Dalam Praktik Pelayanan di Perpustakaan Daerah Kolaka Utara. Pendekatan yang digunakan dalam penelitian adalah menggunakan pendekatan deskriptif kualitatif. Yang di susun terdiri dari 8 orang informan, 3 orang pustakawan dan 5 orang pemustaka. Teknik pengumpulan data yang digunakan yaitu observasi, wawancara, dan dokumentasi. Hasil Penelitian ini menunjukan bahwa, Etika Profesi Pustakawan Dalam Praktik Pelayanan telah diterapkan oleh Pustakawan dengan baik sesuai dengan aturan yang tertulis di dalam Kode Etik Pustakawan Indonesia khususnya pasal 3 ayat 6 tentang sikap sopan dan bijaksana Pustawan dalam memberikan pelayanan. Hal ini dibuktikan melalui observasi dan wawancara langsung di Perpustakaan Daerah Kolaka Utara
\end{abstract}

Kata Kunci : Perpustakaan, pustakawan, etika pustakawan

\begin{abstract}
The purpose of this study was to determine the application of the Librarian Profesional Ethics in Service Practice in The Library in The North Kolaka Area. The approach used in research is to use a qualitative descriptive approach. Which consisted of 8 informants, 3 librarians and 5 users. Data collection techniques used were observation, interviews, and documentation. The results of this study indicate that the application of the Librarian Profesional Ethics in Service Practice Library has been implemented by the Librarians properly in accordance with the rules written in the Indonesian Librarian Code of Ethics especially article 3 paragraph 6 regarding the polite and wise attitude of the Librarian in providing services. This was proven through direct observation and interviews at the North Kolaka Regional Library.
\end{abstract}

Keywords: Library, librarian, librarian ethics 


\section{PENDAHULUAN}

Dalam pengelolaan perpustakaan peran seorang pustakawan sangat penting karena ketika seorang pemustaka berkunjung ke perpustakaan untuk mencari informasi atau bahan pustaka maka orang tersebut akan bertanya kepada seorang pustakawan, seorang pustakawan yang baik harus mempunyai etika dalam memberikan informasi kepada seorang pemustaka. Etika merupakan ilmu yang membicarakan masalah perbuatan atau tingkah laku manusia, mana yang dapat dikatakan baik ataukah tidak/jahat. Perpustakaan merupakan lembaga yang di dalamnya terdapat berbagai macam informasi mengenai ilmu pengetahuan untuk menunjang aktifitas pembelajaran dengan tujuan mencerdaskan bangsa. Selain tempat pembelajaran dan sumber informasi, perpustakaan dapat dijadikan sebagai tempat rekreasi yang menyenangkan dan menambah wawasan pengunjung mengenai ilmu pengetahuan.

Perpustakaan yang baik dapat dilihat dan diukur dari keberhasilannya dalam memenuhi kebutuhan pemustakanya dan dapat melayani dengan kemampuan yang dimiliki pustakawan. Peran pustakawan yang professional, yang meiliki etika yang baik, sangat penting dalam pengelolaan perpustakaan terutama pada bagian pelayanan, guna untuk menarik perhatian dan kepuasan pemustaka saat berkunjung keperpustakaan.

Kode Etik Pustakawan merupakan pedoman bagi pustakawan dalam menjalankan tugasnya. Kode etik akan menjadi pegangan, tuntunan moral dan rujukan bagi setiap pustakawan. Kode etik disusun oleh organisasi profesi sehingga masing-masing profesi memiliki kode etik tersendiri, begitupun dengan pustakawan. Profesi pustakawan memiliki kode etik yang bertugas mengatur sebuah moral atau prilaku pustakawan sebagai anggota profesinya.

Profesi pustakawan bukan hanya sekedar pekerjaan, akan tetapi suatu pekerjaan yang membutuhkan keahlian khusus dan penuh tanggung jawab dalam bekerja. Semakin baik pustakawan tersebut maka semakin baik pula perpustakaan yang dikelolahnya. Berdasarkan Undang-Undang RI Nomor 43 Tahun 2007 tentang Perpustakaan dalam pasal 1 ayat (8) dinyatakan bahwa pustakawan adalah seseorang yang memiliki kompetensi yang diperoleh melalui pendidikan dan/atau pelatihan kepustakawanan serta mempunyai tugas dan tanggung jawab untuk melaksanakan pengelolaan dan pelayanan perpustakaan.

Perpustakaan Daerah Kolaka merupakan perpustakaan terbesar yang terletak di daerah Kolaka Utara tepatnya di Kecamatan Lasusua. Berdasarkan observasi awal yang penulis lakukan di Perpustakaan Daerah Kolaka Utara, Etika Pustakawan di Perpustakaan Daerah Kolaka Utara belum diterapkan dengan baik, karena berdasarkan hasil pengamatan yang dilakukan penulis ketika berkunjung ke Perpustakaan Daerah Kolaka Utara, pustakawanya belum memberikan pelayanan dengan etika yang seharusnya dilakukan oleh Pustakawan dalam memberikan pelayanan kepada pemustaka. Oleh karena itu penulis tertarik untuk meneliti tentang Etika profesi pustakawan dalam praktik pelayanan di Perpustakaan Daerah Kolaka Utara

Penelitian ini mengkaji tentang etika profesi pustakawan yang di atur dalam kode etik tentang sikap dasar pustakawan dalam Pasal 3 ayat 6 yakni, bersifat sopan dan bijaksana dalam melayani masyarakat, baik dalam ucapan maupun perbuatan. Dan juga berlandaskan teori Sifat yang di kembangkan oleh, James C. McCorskey, John A. Daly dan Michael Beatty. (Beverly Hills,CA.1984) teori ini menjelaskan sebuah kualitas atau karakteristik pembeda, ini merupakan cara berfikir, merasakan, dan bertingkah laku yang konsisten terhadap situasi. Bagaimana anda berkomunikasi dalam situasi tertentu tergantung pada sifat yang anda perlihatkan sebagai seorang individu dan situasinya atau lingkungan di manana anda dapat menemukan identitas anda sendiri.

Pada prinsipnya, dilihat dari sudut materinya, maka tugas pokok pustakawan, arsiparis dan dokumentasi adalah sama-sama berbeda. Terdapat beberapa etika yang harus diaplikasikan dalam kehidupan oleh para pustakawan ataupun arsiparis dan dokumentalis, yaitu; (1) jujur, (2) berbicara dengan baik, (3) sopan, (4) sabar, (5) menolong secara baik, dan (6) pelayanan yang baik.

Suwarno (2013:88) menjelaskan, salah satu komponen penting dari perpustakaan adalah pustakawan. Pustakawan sangat di perlukan untuk memberikan pelayanan kepada pengguna perpustakaan sampai mampu memberikan tingkat kepuasan kepada masyarakat yang dilayani. Suwarno (2013:91) mengemukakan dalam lingkup kerja perpustakaan, di tuntut memiliki etika 
agar tercipta interaksi yang harmonis dan suasana kerja yang kondusif, sehingga pemustaka merasa nyaman dan puas terhadap pelayanan yang diberikan. Terdapat beberapa etika yang dapat ditinjau dari beberapa pandangan. Dalam sejarah lazimnya pandangan ini dilihat dari segi filosofis yang melahirkan etika filosofis, ditinjau dari segi teologis yang melahirkan etika teologis, dan ditinjau dari pandangan sosiologis yang melahirkan etika sosiologis.

Pustakawan adalah seorang yang mengelolah sebuah Perpustakaan beserta isinya, memilih buku, dokumen dan materi non buku yang merupakan koleksi Perpustakaan dan menyediakan informasi dan jasa peminjaman guna memenuhi kebutuhan pemakainya (Sulistyo-Basuki 2008). Kemudian dalam Harold's librarians "glosary and reference Book" (Prytherch.2000) Pustakawan adalah one who has care of a library and its content, the work includes selection of stock, its arragement and exploitation in the widest sense, and the provision of a range ofservicein thebest interisis of all groups of user.

Menurut Kanter ( 200:11), sebuah profesi adalah sebutan atau jabatan dimana orang yang menyandang memiliki pengetahuan khusus yang di perolehnya melalui training atau pengalaman lain, atau di peroleh melaui keduanya, sehingga menyandang profesi dapat membimbing atau memberi nasihat /saran atau juga melayani orang lain dalam bidangnya sendiri, profesi dapat dirumuskan sebagai nafkah hidup dengan mengandalkan keahlian dan keterampilan yang tinggi dan dengan melibatkan komitmen pribadi ( moral ) yang mendalam ( Keraf 1998).

Profesi pustakawan memiliki beberapa fungsi yaitu:

- Menjadi mitra bagi para pengguna. Menjadi mitra artinya harus turut mengambil bagian penting dalam kegiatan pengembangan akademik, ataupun penelitian.

- Keahlian melek informasi. Saat ini pustakawan dituntut tidak hanya trampil mengurusi buku atau jenis media informasi lain.

Perpustakaan sebagai suatu pranata diciptakan dan diadakan untuk kepentingan masyarakat. Mereka yang berprofesi sebagai pustakawan diharapkan memahami tugas untuk memenuhi standar etika dalam hubungannya dengan perpustakaan sebagai suatu lembaga, pengguna, rekan pustakawan, antar profesi dan masyarakat pada umumnya. Kode etik pustakawan mengatur sebagai pedoman kerja bagi pustakawan, tujuan kode etik pustakawan adalah agar pustakawan profesional dalam memberikan jasa sebaik-baiknya kepada pemustaka. Hal tersebut dilakukan untuk menjaga martabat pustakawan, meningkatkan mutu dari profesi pustakawan, meningkatkan kualitas layanan dan mencegah kesalah pahaman dan konflik antar anggota dan masyarakat.

Inti dari kegiatan layanan perpustakaan adalah membantu memenuhi kebutuhan informasi bagi pemustaka. Jenis-jenis layanan yang diberikan kepada pemustaka dengan pertimbangan sarana yang dimiliki perpustakaan,jumlah staf,atau pustakawan yang dimiliki, luas sempitnya cakupan koleksi yang ada, serta kebutuhan pemustaka akan jenis layanan tertentu. Pada umumnya layanan yang disediakan perpustakaan adalah:

- Layanan Sirkulasi. Layanan sirkulasi merupakan layanan peminjaman koleksi perpustakaan untuk dibawa pulang. Biasanya layanan ini diberikan kepada anggota perpustakaan. Untuk itu, perlu ditetapkan kebijakan dalam hal keanggotaan dan peminjaman.

- Layanan Referensi. Layanan referensi adalah layanan informasi dengan menggunakan buku referensi sebagai sumber rujukan.

- Layanan Ruang Baca. Layanan ruang baca adalah layanan yang diberikan perpustakaan berupa tempat untuk kegiatan membaca di tempat bagi mereka yang tidak berniat meminjam buku perpustakaan untuk dibawa pulang. Fasilitas di ruang baca yang biasa disediakan adalah meja besar dengan beberapa kursi, meja belajar individu (study carrel) atau tempat membaca santai dengan karpet dan bantal.

- Layanan Audio Visual, yaitu layanan peyediaan koleksi audio visual (pandang dengar) seperti VCD, DVD, CD Audio atau video.

- Layanan Bercerita. Layanan ini umumnya disediakan di perpustakaan sekolah dasar dan taman kanak-kanak. Layanan ini tidak diberikan kepada individu tapi untuk kelompok atau kelas dan diselenggarakan pada waktu-waktu yang telah dijadwalkan. 
- Layanan Kemas Ulang Informasi. Jenis-jenis layanan menurut Hartono (2016) ada 8 jenis diantaranya adalah layanan ruang baca, layanan layanan sirkulasi, layanan referensi, layanan abstrak dan indeks, layanan informasi mutakhir, layanan fotocopi, layanan literatur dan layanan koleksi khusus.

\section{METODE PENELITIAN}

Penelitian ini telah dilakukan di Dinas Perpustakaan Kabupaten Kolaka Utara. Penelitian ini adalah penelitian kualitatif, dengan informan penelitian berjumlah 3 orang pustakawan dan 5 orang pemustaka. Teknik penentuan informan pada penelitian ini dilakukan dengan teknik accidental sampling. Teknik pengumpulan data menggunakan metode observasi, wawancara, dan dokumentasi. Data penelitian yang diperoleh dianalisis menggunakan analisa deskripsi kualitatif. Adapun definisi operasional variabel penelitian disajikan pada tabel berikut.

Tabel 1 Desain Opersional Variabel Penelitian

\begin{tabular}{|c|c|c|}
\hline Unit Analisis & $\begin{array}{c}\text { Struktur Kerangka } \\
\text { Analisis }\end{array}$ & $\begin{array}{c}\text { Teknik Pengumpulan } \\
\text { Data }\end{array}$ \\
\hline $\begin{array}{l}\text { Penerapan Etika Profesi } \\
\text { Pustakawan Dalam }\end{array}$ & & \\
\hline Memberikan Layanan & 1. Bijaksana & Observasi \\
\hline Informasi Di Dinas & 2. Sopan Santun & Wawancara \\
\hline $\begin{array}{l}\text { Perpustakaan Kabupaten } \\
\text { Kolaka Utara }\end{array}$ & & Dokumentasi \\
\hline
\end{tabular}

\section{HASIL DAN PEMBAHASAN}

Pustakawan dalam memberikan pelayanan kepada pemustaka memiliki peran penting. ketika pemustaka berkunjung ke perpustakaan untuk mencari informasi atau bahan pustaka maka pemustaka tersebut akan bertanya kepada pustakawan, pustakawan yang baik mempunyai etika dalam memberikan informasi kepada pemustaka dan hal itupun di atur dalam kode etik pustakawan.

Pustakawan dalam memberikan pelayanan informasi terkait dengan kebutuhan pemustaka di atur dalam kode etik pustakawan. Dalam penelitian ini kajiannya terkait dengan etika pustakawan dalam memberikan informasi diperpustakaan Daerah Kolut. Untuk melihat hal tersebut, dilaksanakan melalui bagaimana penerapan sikap sopan dalam tindakan maupun ucapan dan sikap bijakasana pustakawan dalam melayani dan memberikan informasi kepada pemustaka.

Sikap sopan dalam tindakan dan ucapan berkaitan dengan perilaku pustakawan di perpustakaan Daerah Kolut dalam memberikan pelayanan kepada pemustaka dengan mengedepankan keramahan, bersahabat, berfikir positif, dewasa, tidak egois, tulus, ikhlas, dalam memberikan pelayanan terbaik. Sedangkan sikap bijaksana berkaitan dengan apa yang diberikan pustakawan terkait informasi yang dibutuhkan pemustaka dengan tidak membeda-bedakan artinya harus sesuai dengan hati nurani yang baik dan selalu berhati-hati dalam mengambil keputusan sehingga menghasilkan tingkah laku yang baik yang tidak menyimpang dari normanorma kehidupan dan kemanusiaan.

Sikap Sopan Pustakawan Dalam Memberikan Layanan Informasi. Sebagaimana telah dijelaskan sebelumnya bahwa sikap sopan dan santun merupakan norma yang tidak tertulis yang mengatur bagaimana seharusnya berperilaku dan bersikap dengan baik terhadap orang lain. Sebagai pustakawan yang setiap harinya harus berhadapan dengan banyak pemustaka maka sudah seharusnya hal itu juga diterapakan. Sikap sopan yang dimaksud adalah cara pustakawan berkomunikasi dengan pemustaka dalam hal pemenuhan kebutuhan informasi.

Berdasarkan hasil wawancara dengan beberapa informan, dapat disimpulkan bahwa bahwa seorang pustakawan yang terampil dan profesional tidak mengaitkan masalah apapun yang terjadi di luar dengan pelayanan yang di lakukan di perpustakaan. Sebagai pustakawan yang 
profesional sudah seharusnya memilah antara kejadian yang terjadi di luar perpustakaan dan profesi yang ditekuni.

Pustakawan adalah bagian dari masyarakat, sekaligus sebagai abdi masyarakat dalam hal pelayanan informasi. Kaitannya dengan pelayanan ini, etika menghendaki agar pustakawan bersikap sopan kepada pemustaka yang berinteraksi dengannya. Dalam melayani pengguna, pustakawan harus bersikap sopan. Sopan dapat dilakukan misalnya dengan senyum, sapa dan salam kepada pemustaka dan apabilah ada yang membutuhkan pertolongan misalnya kesusahan mencari koleksi yang ia butuhkan sebagai pustakawan yang baik haruslah memberikan arahan kepada pemustaka tersebut dimana letak koleksi yang pemustaka butuhkan (Pramadi, 2016:54). Sopan berjalan beriringan dengan bijaksana, sehingga perilaku pustakawan dapat memuaskan pemustaka perpustakaan.

Dari data yang diperoleh di lapangan yang dilakukan dengan wawancara langsung kepada pemustaka dan pustakawan, dokumentasi, serta studi pustaka ini menunjukkan bahwa pustakawan di Perpustakaan Daerah Kolaka Utara selalu bersikap sopan dalam melayani pemustaka baik dalam ucapan maupun perbuatan dan itu tergambar dalam tindakan mereka dalam memeberikan pelayanan ketika ada yang kesusahan mecari koleksi, kebingungan karena baru pertama kalinya datang ke Perpustakan dan pustakawan dalam hal ini sudah mengarahkan dengan baik karena setiap pustakawan perpustakaan Kolut mengerti bahwa setiap pekerjaan yang dilaksanakannya tidak lepas dari interaksi dengan orang lain, untuk menjaga martabat dan profesinya pustakawan harus bersikap sopan dalam melayani pemustaka.

Sikap Bijaksana Pustakawan dalam Memberikan Layanan Informasi. Sikap bijaksana merupakan sikap tepat dalam menyikapi setiap keadaan dan peristiwa sehingga memancarkan keadilan, kebeningan hati dan tanpa membeda-bedakan pemustaka yang datang ke perpustakaan. Bijaksana merupakan sifat yang juga harus dimiliki oleh pustakawan. Pustakawan yang yang merupakan pelayan publik sudah seharusnya memiliki sifat tersebut karena setiap hari harus bertemu dengan banyak pemustaka, baik itu yang di kenali maupun yang tidak dikenali. Dalam hal inilah dapat di lihat apakah bijaksana sudah diterapkan dengan baik.

Berdasarkan hasil wawancara bersama beberapa informan, dapat dikatakan bahwa sebagai pustakawan yang profesional, kepentingan pemustaka dan pelayanan yang baik merupakan prioritas utama pustakawan dalam memberikan layanan informasi di perpustakaan. Dengan tidak membeda-bedakan siapa yang datang mencari informasi di perpustakaan. Baik itu dari kalangan mahasiwa, Pelajar, dosen, Guru, maupun masyarakat Umum, yang membutuhkan literatur.

Perpustakaan sebagai tempat informasi ini tidak lepas dari campur tangan pustakawan sebagai pengelolanya, yang kemudian peranan di atur dalam kode etik pustakawan. Dari kewajiban ini, pustakawan mempunyai pengalaman serupa. Pada saat pemustaka sedang mencari koleksi, tetapi koleksi tersebut tidak ada ditempat lalu pustakawan mengarahkan pengunjung untuk mencari buku tersebut ke tempat lain dan pustakawan membantu pemustaka menemukan buku tersebut. Pustakawan berpendapat bahwa itu sudah menjadi tugas wajib seorang pustakawan. Dengan demikian pustakawan menyediakan akses tak terbatas bahkan pustakawan bersedia mencarikan di perpustakaan-perpustakaan lainnya dengan menelpon ke perpustakaan tersebut.apakah perpustakaan tersebut mempunyai koleksi yang dituju. Bijaksana dalam hal ini bukan hanya sebatas itu saja akan tetapi tentang sikap pustakawan dalam memberikan layanan informasi apakah sudah sesuai dengan hati nurani yang baik, yang selalu berhati- hati dalam mengambil keputusan, tidak membeda-bedakan pemustaka yang datang ke perpustakaan sehingga menghasilkan tindakan yang baik tanpa adanya diskriminasi terhadap kalangan tertentu.

Selain memiliki kewajiban untuk menjalankan tugas sebagai seorang profesional, pustakawan juga memiliki kewajiban sebagai seorang individu, baik di lingkungan keluarga maupun masyarakat. Sekalipun terdapat konflik diri sebagai individu, namun tetap dituntut untuk tetap bersikap profesional. Dari hasil yang diperoleh di lapangan, para pustakawan dalam penelitian ini sudah mampu membedakan sikap hidup pribadi dan tugas profesi.

Sudah menjadi suatu yang diwajibkan bahwa dalam memutuskan segala tindakannya, pustakawan harus mampu bersikap profesional tanpa membeda-bedakan antara pemustaka satu 
dengan yang lainnya. Keputusan yang di ambil dan lakukan demi kepentingan pengguna, bukan untuk kepentingan pribadi. pustakawan melakukan pekerjaan sesuai dengan taat aturan, bekerja dengan tepat waktu dan bersungguh-sungguh, bertanggung jawab atas pekerjaan yang dikerjakan dan tidak memandanga ras, agama, status sosial dan lain sebagainya antar pengunjung yang berkunjung. pustakawan sudah melakukan tugas dengan profesional dan sesuai dengan kemampuan yang dimiliki masing-masing pustakawan yang ada di Perpustakaan Daerah Kolaka Utara.

\section{KESIMPULAN}

Hasil analisis data yang dilakukan dilapangan maka kesimpulan yang bisa ditarik oleh peneliti bahwa sikap sopan pustakawan di Perpustakaan Daerah Kolaka Utara sudah memenuhi standar Kode Etik Pustakawan hal tersebut tergambar melalui cara pustakawan dalam memberikan layanan dengan mengedepankan berpikir positif, Dewasa, tidak egois, tidak cuek dan tulus. Dan sikap bijaksana pustakawan dalam memberikan layanan informasi kepada pemustaka juga telah terpenuhi dengan baik. Hal tersebut tergambar melalui cara pustakawan dalam mengambil tindakan apabila ada pemustaka yang kurang memahami aturan yang diberlakukan di Perpustakaan Daerah Kolaka Utara, berhati-hati mengambil keputusan, bersikap adil serta tidak membeda-bedakan pemustaka yang datang ke perpustakaan.

Berdasarkan hasil penelitian yang telah diperoleh, maka ada beberapa saran yang bisa penulis berikan. Pertama, kepada perpustakaan Daerah Kolaka Utara dalam hal ini pustakawanuntuk terus memberikan pelayanan yang terbaik kepada pemustaka sesuai dengan kode etik pustakawan yang berlaku agar pemustaka merasa nyaman dan puas dengan pelayanan yang diberikan pustakawan sehingga pemustaka akan lebih sering berkunjung ke perpustakaan. Kedua, kepada Perpustakaan Daerah Kolaka Utara Kode Etik yang baik apabilasudah diterapkan dengan baik harus juga ditunjang dengan fasiltas yang baik dalam hal ini mengenai koleksi yang perlu diperbaharui dalam periode yang ditentukan sehingga ilmu dan pengetahuan terus terupdate sesuai dengan kebutuhan pemustakanya. Ketiga, kepada pemustaka, diharapkan pemustaka dapat memberikan saran dan kritik apabilah mendapatkan pelayanan yang kurang baik dari pustakawan. .

\section{DAFTAR PUSTAKA}

Agniken, Sinda.2010. Penerapan Kode Etik Pustakawan di Perpustakaan niversitas Negeri Padang, Skripsi. Universitas Negeri Padang.

Basuki, Sulistyo. 2008. Pengantar Ilmu Perpustakaan. Jakarta. Universitas Terbuka.

Effendi, Maizuar. 2014. Kode Etik dan Profesionalisme Pustakawan. Makalah.

Hermawan, R.S dan Zen, Z. 2006. Etika Kepustakawanan:Suatu Pendekatan Terhadap Kode Etik Pustakawan Indonesia. Jakarta: Sagung Seto.

Ikbar, Yanuar. 2012. Metode Penelitian Sosial Kualitatif. Bandung: Refika Aditama.

Jafar Khadijah ST. 2015. Penerapan Kode Etik Pustakawan di Perpustakaan Universitas Islam Negeri Alauddin Makassar. Skripsi. Makassar: Univesitas Islam Negeri Alauddin Makassar .

Kode etik Pustakawan. Tentang sikap dasar pustakawan dalam Pasal 3 ayat 6 yakni, bersifat sopan dan bijaksana dalam melayani masyarakat, baik dalam ucapan maupun perbuatan.

Masruriyah.Nunung. 2009. Perilaku Pencarian Informasi Dalam Memenuhi Kebutuhan Informasi Mahasiswa UIN Syarif Hidayatullah. Skripsi. Jakarta: Universitas Islam Negeri Syarif Hidayatullah.

Riani. Nur. 2017. Model Perilaku Pencari informasi Guna Memenuhi Kebutuhan Informasi (Studi Literatur).Skripsi.Yogyakarta: UIN Sunan Kalijaga Yogyakarta.

Rompon. Erin. 2018. Etika Pustakawan Dalam Memberikan Informasi Kepada Pemustaka Di UPT Perpustakaan Universitas Halu Oleo. Skripsi. Kendari: Universitas Halu Oleo Kendari.

Sinaga, Dian. 1991. Ilmu Perpustakaan dan Profesi Pustakawan. Bandung: Bina Cipta.

Sutamo, Ns. 2006. Perpustakaan dan Masyarakat. Jakarta:Cv.Sagung Seto 
Setiawan, Rahmat. 2017. Pengembangan Profesionalisme Pustakawan Melalui Pendekatan Etika Moral. Skripsi. Surakarta:Universitas Sebelas Maret.

Undang-Undang RI Nomor 43 Tahun 2007. tentang Perpustakaan dalam pasal 1 ayat (8).

Winoto, Yunus. 2015. Penerapan Teori Kredibilitas Sumber (Source Of Credibity) Dalam Penelitian - Penelitian Layanan Perpustakaan. Skripsi. Universitas Padjadjaran.

Yuliani, Tri. 2017. Etika Profesi Pustakawan Dalam Praktik Pelayanan di Perpustakakaan UIN Sunan Kalijaga Yogyakarta. Skripsi. Yogyakarta: Universitas Islam Negeri Sunan Kalijaga Yogyakarta.

Zuriah, Nurul. 2011. Pendidikan Moral dan Budi Pekerti Dalam Perspektif Perubahaan. Jakarta: Bumi Aksara.

\section{Sumber Online}

Afriana, Cut Rika. 2016. Etika Profesi Pustakawan di Perpustakaan. Makalah Diakses dari http://hecalibrary.blogspot.com/2016/10/etika-profesi-pustakawan diperpustakaan.html?m=1 diakses pada tanggal 2 Oktober 2019

Elhasany, Zain. 2016. Cara menulis daftar pustaka lengkap dengan contohnya. Diakses dari http://www.penaindigo.com/2016/08/cara-menulis-daftar - pustakalengkap.htmldiakses tanggal 3 Oktober 2019 